\title{
Private Participation in Infrastructure: The Nigerian Experience
}

\author{
Mohammed Aliu Momoh ${ }^{1}$ \\ ${ }^{1}$ Department of Finance, Faculty of Management Science, University of Lagos, Nigeria \\ Correspondence: Mohammed Aliu Momoh, Ph.D., Department of Finance, Faculty of Management Science, \\ University of Lagos, Lagos, Nigeria. Tel: 234-802-307-0381. E-mail: alimomoh@gmail.com
}

Received: June 27, 2018

Accepted: August 15, 2019

Online Published: August 18, 2019

doi:10.5539/ijef.v11n9p55

URL: https://doi.org/10.5539/ijef.v11n9p55

\begin{abstract}
The participation of the private sector in the provision of infrastructure is now a fundamental element of discourse around state modernization especially in the face of fiscal crisis. This paper examines the dialogue against the backdrop of the impression that the concept is new as a tool of fiscal management as well as its adoption in the emerging economies using Nigeria as a reference point. The study traced the evolution, theoretical foundation and history of public private partnership in Nigeria. Our findings reveal that though the adoption of PPP has been positive, it has some challenges, which are as a result of contract term agreement, political influence and the need for renegotiation as a result of increasing cost and those conditions are not envisaged at the time of contracting.
\end{abstract}

Keywords: infrastructure, procurement, public private partnership, economic growth, Nigeria, investment in infrastructure

\section{Introduction}

The role and contributions of infrastructure to economic development has long been established as impacting and having a long term effect on poverty alleviation, equality, growth and specific development outcomes such as job creation, transportation, market access, health and education (Straub, 2008; Calderon et al., 2011; Schwartz et al., 2009; Calderon \& Serven, 2010; Estache et al., 2013). Nedozi et al. (2014) and Kim (2006) opined that infrastructure is indispensable to achieve the main development targets and should be given adequate attention given that the poor state of infrastructure in Africa according to Mayaki (2014) reduces national economic growth by two percentage points every year and cut business productivity by as much as $40 \%$ despite its huge potentials.

Calderon and Serven (2010) also confirmed in their study that the quantity and quality of infrastructure have a positive and significant impact on increasing growth rates. Unfortunately, the global financial crisis presents enormous challenges to the delivery of infrastructure requiring a global investment of around $\$ 71$ trillion by 2030 to keep up with population growth and demand (Sachs et al., 2004; Barker et al., 2009). This has necessitated the recent policy shift in developing countries towards the private sector for provision of many goods and services traditionally viewed as "public goods" putting into question the role of government in economic progress and provided governments with a new paradigm. Many governments now seek to involve the private sector in the provision and financing of infrastructure services (Harris, 2003; Chatterjee \& Morshed, 2011) in a process referred to as Public Private Partnership (PPP).

Asia Development Bank (2010) posits that PPPs can follow a variety of structures and contractual formats. It goes further to opine that a successful PPP is designed with careful attention to the context or the enabling environment within which the partnership will be implemented, taking into consideration the reform objectives, policy environment, legal and institutional frameworks, financing requirements, political constraints and stakeholder concerns.

Private participation in provision of infrastructure therefore constitutes a fundamental element of the discourse around state modernisation, encompassing several different families of activities and can be defined in relation to the rules governing the choice of private partners and the selection and application of public procurement procedures for infrastructure. (European Commission, 2003; Weihe, 2005; Hodge \& Greve, 2007; and Hudon, 2011). Yescombe (2007) and Markab Advisory (2012) argue that Public-Private Partnerships (PPP) represent the middle ground between the traditional model for infrastructure development and outright privatisation through 
the sale of government assets to the private sector. PPPs also signify a philosophical shift, which recognises the fact that the private sector could provide many public services and much of infrastructure more efficiently than the governments.

The rationale for this paper is to advance the argument that private participation in the provision of infrastructure is not new especially in Nigeria thus supporting Tiča and Zajc (2010) who posited that PPPs are treated primarily as economic partnerships or a special form of hybrid cooperation between public and private sectors acting as a catalyst for improvement in efficiency through the introduction of incentives to reduce wasteful costs with substantial improvement in welfare and fiscal gains (Ros, 1999; Bortolotti et al., 2001; Sunita \& Nellis, 2002; and Clive et al., 2003).

This paper is divided into five parts, the introduction which examines the background to this study. The second part examines the evolution of public- private partnership and the theoretical underpin, then the history of private participation in infrastructure in Nigeria in part three and the fourth part examines the experience of Nigeria between 1997 and 2011 with conclusion in part five.

\section{Evolution of the Public Private Partnership}

According to Groote (1995) and Wiegmans et al (2005), governments since the Napoleonic time have played an active role investing in infrastructure as a form of intervention to safeguard social interests. Unfortunately, infrastructure needs in recent times have outpaced the public sector's financing capabilities thus necessitating governments inclination towards the private sector for additional provision of financing and expertise for the construction and management of critical infrastructure projects because governments assume that the involvement of private actors will generate better results and added value (Osborne, 2000; Ghobadian et al., 2004; Hill, 2004).

Markab Advisory (2012) maintain that there would always be a debate on the actual origins of Public Private Partnership although Auriola and Picard (2011) argued that the first concessions were granted for the construction of turnpike roads in the UK in 1660, at a time of industrial expansion and embryonic public finances, followed by the concession granted to the Périer Brothers in 1782 to pump and supply water to the city of Paris and followed in other parts of Europe such as France, Spain, Italy, Belgium, and Germany.

Evaluating the development of global private participation in infrastructure, Wiegmans et al. (2005) in their study identified three phases in which investments in infrastructure were treated differently. The first period runs from around the WW2 up to 1960. This was a period of rebuilding Europe, which lent itself pre-eminently for (intensive) cooperation between government and private parties. Many infrastructure projects were executed by means of a form of PPP. This however, changed in the 1960s, making cooperation difficult as a result of the growing differences between public and private goals. These differences in goals, suspicion and mistrust replaced the cooperation of the first phase and essentially defined the second phase between 1979 and 1982. During this phase, social objectives in governmental policy played an important role as a result of which less space was available for input of businesses thus cooperation between the public and private sector in investments in infrastructure hardly took place. The third phase was identified as covering the period from 1982 to date. According to Wiegmans et al. (2005), the beginning of this period is characterised by economic decline and high unemployment rates. To address these challenges, governments have focused on core tasks, deregulating sectors, decentralising and privatising investment, which created more opportunities for business initiatives.

PPP as the key tool of public policy across the world can be traced to the mid-nineties as an outcome of New Public Management (NPM) order. It follows the collapse of the central planning model of the former Soviet Bloc as well as the privatisation of state assets by the western governments and the desire for quicker methods of financing, planning and execution of large-scale projects. NPM shifted the focus of management from public service to service delivery, a delegation of responsibilities to the private sector, or put differently, fostering of voluntary engagement of private sector aimed at providing public goods. The principles of NPM encouraged the establishment of Public Private Partnerships (PPPs) as a new management tool (Mitchell-Weaver \& Manning, 1991; Osborne, 2000; Reside \& Mendoza, 2010; and Markab Advisory, 2012).

The contemporary era of PPP however, can be traced back to the Private Finance Initiative ("PFI") introduced by the UK government in 1992 and re-branded under the umbrella of Public Private Partnerships in 1997. The objective was for the provision of public capital assets and support services by a private sector consortium in exchange for a stream of (unitary) payments over the life of the contract. Overtime, it became the principal methods for procuring long-term public sector capital projects and delivering associated services in the face of the global financial crisis (HM Treasury, 1997; Broadbent \& Laughlin, 2005; Grimsey \& Lewis, 2005; Khadaroo, 2005; Confederation of British Industry, 2007; Zheng \& Caldwell, 2008; Raisbeck et al., 2010; Markab Advisory, 
2012).

This support the findings of Hammami et al (2006) that PPPs tend to be more common in countries whose governments suffer from heavy debt burdens, where aggregate demand is sizable, and where markets are large enough to allow for cost recovery. They concluded that macroeconomic stability is essential for PPPs because partnerships are more common in countries with low inflation. Nevertheless, Vining and Boardman (2008) observed there are inherent conflicts in complex PPPs that can cause difficulties between project partners because there is a divergence of goals between public and private partners with the private sector seeking to maximize profits and the government agency seeking to minimize current cost.

In a survey by Kwak et al. (2009) they found that the success or failure of a PPP project is dependent on four groups of factors: the competence of the government, the selection of an appropriate concessionaire, an appropriate risk allocation between the public and private sectors, and a sound financial package. Bloomfield (2006) suggested that long term PPP contracts need to be approached with caution and that it has often been recognised that business transactions between government and private companies are more likely to serve public objectives when competition is robust, when measurable performance requirements can be specified in advance, when the contractor can be readily replaced, and when the transactions are transparent.

Hodge and Greve (2011) observed that despite the loud voices of critics and harsh judgments of some academics, the growth of public private partnership in the past few decades have remained a paradox. In understanding the consistency in the growth of public private partnerships, there is a need to examine its theoretical foundation, which forms the rationale for the adoption of PPP as a procurement model.

\section{Theoretical Foundation of Public Private Partnership}

According to Hammami et al. (2006) the concept of Public Private Partnership can theoretically be traced to the theory of x-efficiency developed by Leibenstein (1966). The theory is anchored on the idea "that public institutions or enterprises cannot fail as long as official financial and monetary policies are expansionary enough to bail them out or to limit their probability of failure. Vining and Boardman (2008) explain that governments engage in much more diverse activities and usually have less specific expertise or experience with the relevant technology or activity, and the monopoly public-sector bureaucracies are particularly prone to technical or $\mathrm{X}$-inefficiency. These inefficiencies result from both distortionary government interventions as well as states' organisational structures, which are typically highly bureaucratic. Hence, according to this theory, public-private partnerships are necessary to reduce the sources of $\mathrm{x}$ - inefficiency in public organisations and to allow them to respond to market forces and become more competitive.

The major argument therefore is that private-sector firms have superior scale, scope or learning economies because they are more specialised, larger and have more experience with incentives to minimise costs and, as a result, to squeeze out and lower potential agency costs. These incentives are likely to become most evident in the dynamic aspects of projects they executive (Jensen \& Meckling, 1976; Dosi, 1988; Vining \& Boardman, 2008). The implications of the theory according to Hammami et al (2006) are the challenges that countries face arising from fiscal crisis, infrastructure preferences and technical challenges amongst the many problems making infrastructure development difficult to be resolved through PPP arrangements.

However, the normative arguments and fierce opposition to the modern form of public-private partnerships state that this organisational form may increase the possible efficiency gains. Holmstrom and Milgrom (1991) argue that incentives on one task might destroy incentives on another when tasks are substitutes in the agent's cost function; a result, which suggests that tasks should be split when there is a negative production externality. PPP alternative as compared with the traditional form of procurement is characterised by two important features. First, the two tasks of building and managing assets are now bundled. Second, the ownership pattern is also quite different. Bundling allows a better internalisation of this externality and it improves incentives when the externality is positive, thereby increasing welfare (Martimort \& Pouyet, 2006).

The next part of this paper is to examine how the concept evolved and has faired in Nigeria tracing its history and the participation for the growth of infrastructure.

\section{History of Private Participation in Infrastructure in Nigeria}

For Nigeria, PPPs in the infrastructure sector according to Adekunle (2011) is a post-1999 reform factor, representing a fundamental economic ideological shift, as it gives the private sector a greater stake in the management of the economy. PPPs also offer the government a huge relief from the biting effects of the global financial crisis. Ohia (2011) argues that the legal framework for the operation of infrastructure concessions in Nigeria was done through the enactment of the Infrastructure Concession Regulatory Commission Act 2005 and 
the Public Procurement Act 2007, which set out the requirements for competition and private sector participation in all public procurements as well as specifying the requisite approvals for all PPP contracts with the establishment of the Commission in 2008 was the turning point.

However, PPPs according to the Federal Ministry of Health (2005) was not a new concept in Nigeria as there has been various attempts in developing a public private partnership relationship. Prior to independence, the Lagos Chamber of Commerce and Industry was established in 1888, with the objective of promoting and supporting legislative or other measures affecting trade, industry, commerce and agriculture as well as representing the opinion of the business community (Lagos Chamber of Commerce and Industry, 2013). At independence and up to the late 1970s the focus was on state-led development projects premised on the basic assumption that the state is the primary agent for development with little or no role assigned to the private sector in the development process. Consequently, private sector participation in infrastructure development was not seen as critical even though the sector was not fully matured. (Mabogunje, 2007; and Sagagi, 2007).

Although the creation of the Manufacturers Association of Nigeria (MAN) in 1971 did provide a suitable counterweight to the state or a stimulus to effective public-private sector dialogue, nonetheless, the government was still the major player in the economy up to the 1980s when the Structural Adjustment Program (SAP) was introduced in 1986. This was an attempt to address some of the imbalances in the system and thereby create a wider room for private sector activity. In 1989, the government established the National Committee on Industrial Development (NCID) as the main forum for dialogue with the private sector (Ahmed 1999). The major outcome of the dialogue with the private sector was the first national economic summit and the eventual enactment of the National Planning Commission Act in 1993. The National Planning Commission (NPC) therefore became the agency within government charged with developing an effective dialogue with the private sector (Agboli \& Emery, 2005; and Sagagi, 2007).

Udah and Obguagu (2011) in their study argue that although Nigeria is recognised globally as a country with great potentials in infrastructure investments, the overall picture that emerges is that Nigeria has over-invested in physical capital and has suffered from poor productivity. In their study they find that all major economic and social indicators painted Nigeria in the picture of one of the world's greatest paradoxes amongst others, making the poor performance of public infrastructure services in Nigeria a subject of considerable discussion (Sala-i-Martin \& Subramanian, 2003; Ariyo \& Afeikhena, 2004; and Hassan et al., 2012).

Sotola and Ayodele (2011) however, concluded that the successes recorded during the privatisation programme in the 1980s and the momentum gained since 1999 in telecommunications and waste management services concessions, which resulted in increased access and quality services forced the shift in government thinking to public private provision of infrastructure. This policy change is an answer to the previous challenges in which public authorities are the leaders and dominant partners in PPP contracts, awarding contract and could also cancel same at will. The risk in this leader-follower relationship resulted in the failure experienced in various past concessions at the Nigerian Port Authority (NPA), the Ajaokuta Steel Rolling Mill and the Nigerian Telecommunications Limited (NITEL) among many other examples.

To address these challenges identified by Sotola and Ayodele (2011), the government of the Federation enacted the Infrastructure Concession Regulatory Commission Act 2005 with the objective of developing regulatory and monitoring institutions so that the private sector can play a greater role in the provision of infrastructure, whilst ministries and other public authorities will focus on planning and structuring projects (The Federal Government of Nigeria, 2009). This was necessary because "existing legislations do not have appropriate enabling provisions to support private investment. This is particularly true in Nigeria where the framework is new and there are few laws guiding the implementation (Sotola \& Ayodele, 2011).

\section{Private Participation in Infrastructure - The Nigerian Experience (1997-2018)}

According to Abdullahi and Aziz (2010), over the years, government has played the sole or dominant role in all spheres of the economy including providing public service delivery. Although this model initially produced some desirable results, unfortunately there is a far greater financial need for urban development projects than can be provided by the traditional public purse alone. This has led to serious problems, especially in developing countries. These problems included under-investment caused, to a large extent, by underpricing, low productivity, poor service delivery, long queues, lack of access to basic services; lack of transparency, and damaging political interference in the operations of these infrastructure entities (World Bank, 2004)

When Nigeria became independent in 1960, the dominant economic policy direction and thinking according to Agboli and Emery (2005) was to expand the government's role through direct intervention and ownership in the economy. With the support of the international donor agencies and increased revenue arising from the oil boom 
of the 1970s, the government gained the commanding heights and dominated economic activity in the country. This led to a lower growth in the emerging private sector thus causing a fundamental shift in private sector activity away from agricultural and industrial production to government contracting and trade.

Thus, decades of poor maintenance and underinvestment left the country with a shocking infrastructure shortage thus hindering economic growth. Coupled with the new thinking that creating an environment that promotes and supports entrepreneurship and private investment was a primary function of governments, the experience of the last two decades shows that most countries will be better off working out a partnership with the private sector to achieve sustained efficiency gains and minimize fiscal financing requirements (Agboli \& Emery, 2005; Afeikhena, 2008; and Ohia, 2011). Therefore, the fiscal challenges as well as the awareness that private sector can supply assets and services at lower costs and in a more efficient way, resulted in the introduction of various forms of PPPs (Alasad, 2011).

For Nigeria, the experience with private intervention in the provision of infrastructure especially between 1990 and 2018 has been noteworthy. During this period, the total number of infrastructures reported and reaching financial closure in Sub Sahara Africa totaled 502 projects worth a total investment value of US $\$ 78$ billion. Out of this, the portion attributable to Nigeria, which had its first recorded private participation in infrastructure in 1992 though cancelled, was 54 (forty-nine) projects with a reported value of about US\$12 billion (twelve billion dollars) representing $9.76 \%$ and $14.9 \%$ respectively in the energy, information and communication technology and transport sector (Table 1).

Table 1. Projects and investment by type and investment for Nigeria (1990-2018)

\begin{tabular}{lcccccccccc}
\hline \multirow{2}{*}{ Sector } & \multicolumn{2}{c}{ Brownfield } & \multicolumn{2}{c}{ Divestiture } & \multicolumn{2}{c}{ Greenfield project } & \multicolumn{2}{c}{ Management and lease contract } & Total \\
\cline { 2 - 12 } & No. & $\$$ (mill.) & No & $\$($ mill.) & No & $\$($ mill.) & No & $\$$ (mill.) & \$(mill.) \\
\hline Energy & 2 & 238 & 2 & 687 & 7 & 2,331 & 0 & 0 & 11 & 3,256 \\
ICT & 0 & 0 & 1 & 750 & 9 & 207 & 1 & 0 & 11 & 957 \\
Transport & 27 & 3,059 & 0 & 0 & 5 & 4,700 & 0 & 0 & 32 & 7,759 \\
Water and sewerage & 0 & 0 & 0 & 0 & 0 & 0 & 0 & 0 & 0 & 0 \\
Total & $\mathbf{2 9}$ & $\mathbf{3 , 2 9 7}$ & $\mathbf{3}$ & $\mathbf{1 , 4 3 7}$ & $\mathbf{2 1}$ & $\mathbf{7 , 2 3 8}$ & $\mathbf{1}$ & $\mathbf{0}$ & $\mathbf{5 4}$ & $\mathbf{1 1 , 9 7 2}$ \\
\hline
\end{tabular}

Sources: World Bank Private Participation in Infrastructure Projects Database (PPIPD).

During this period, the transport sector recorded the highest investment of over US\$ 7 billion dollars, representing over 65 percent followed by the energy sector with 11 (eleven) projects with an investment value of over US\$3 billion representing 27 percent of investing activities. The ICT though with 11 (eleven) projects like the energy sector but had a lower investment value of US\$ 957 million with the water and sewage sector recording no project and investment during the period.

When disaggregated into subsectors - Airports, Electricity, ICT, Natural Gas, Ports, Railways and Roads, the port subsector (transport) sector had the largest investment share of about 60 percent of total investment for the period under review, followed by the electricity subsector (energy sector) with about 22 percent. The other subsector, Airports, ICT, Natural Gas, Railways and Roads with an aggregate of less than 18 percent of total investment of US $\$ 11.972$ billion had less than 10 percent investment each recorded during the period under review (see figure 1).

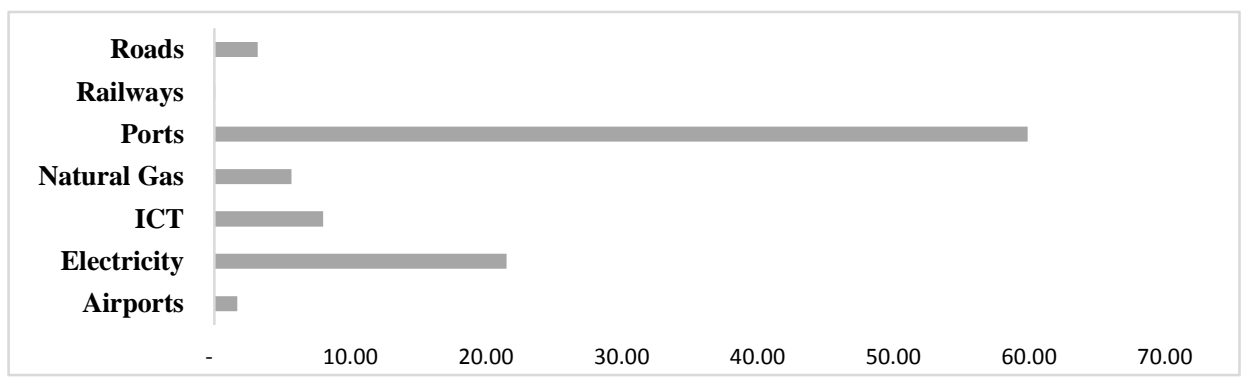

Figure 1. Sub-sector investment in infrastructure in Nigeria

A review of the transport sector shows that the investment in the Ports (Sea and Airports) sub sector which peaked in 2005 and 2013 was largely as a result of the massive Rehabilitate, lease or rent, and transfer (RLRT) and Build, rehabilitate, operate, and transfer (BROT) contract for the country's flagship seaports and airports all 
in nation's commercial capital of Lagos. Also, the new Build, operate, and transfer contract for Murtala Muhammed Terminal Two, PTML Lagos Ro/Ro Terminal, Lekki Deep Seaport, and Build, own, and operate for the Onne port expansion, phase 4B in the Niger Delta region boosted the Port investment. Also, the Build, rehabilitate, operate, and transfer transaction in 2008 and 2011 for the Lekki-Epe Expressway and Bullnose Port Facilities in Lagos respectively enhance the transport sector.

The energy sector segmented into natural gas and electricity sub sector recorded the second highest private participation investment in infrastructure of 27 percent. The investment in this sector especially the electricity subsector with about 22 percent of total, recorded it highest single investment share in 2015 with the US $\$ 880$ million Azura-Edo Gas-Fired Power Plant, Phase 1 in the Niger Delta region on a Build, own, and operate basis as well as prior investment of about US $\$ 1.6$ billion between 2001 and 2005 to 2005 in Greater Lagos gas distribution pipeline, Okpai Independent Power, West African Gas Pipeline and other project which had tremendous impact and contributed to the growth of the sector. (figure 1 and figure 2).

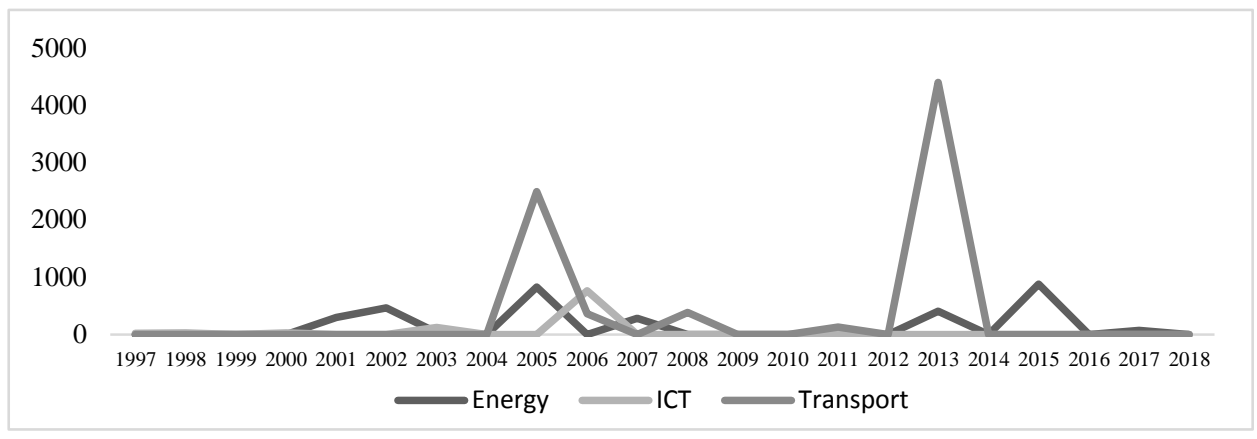

Figure 2. Investments by sector 1997-2018

Furthermore, with an aggregate investment of less than a billion dollars, US\$957 million (see Table 1) representing 8 percent of total investment, though small in aggregate terms, the Information and communication technology recorded some landmark achievement resulting in the changing the face of telecommunication in Nigeria. The investment in this sector was driven by the deregulation of the telecommunication sector in 2001 . This is evident by the over 1000 percent growth in investment in the sector between 2000 and 2003, when the Global System of Mobile (GSM) communication was introduced and in subsequent years up to 2006 as well as the divestiture of government interest in the national telecommunications company (PPIAF, 2014). Unfortunately, the water and sewage sector did not attract any investment during the period under review (PPIAF, 2014).

Although there was no recorded project or investment in the water and sewage sector, Public-Private Infrastructure Advisory Facility has since 1999 supported the national and sub national (Lagos, Kaduna, and Ogun) government of the Federation. According to Public-Private Infrastructure Advisory Facility (2012) of the world bank, the PPIAF provided technical assistance to the Nigerian Ministry of Water Resources in 2006 to prepare the groundwork for private participation in urban and small towns' water supply in states that demonstrate seriousness, through policy and institutional reforms, about getting the private sector involved in the water sector. According to the World Bank Private Participation in Infrastructure Projects Database (PPIPD), during the review period, Nigeria was classified as low middle income under the Income Category with 6 projects and 3 percent of investment cancelled or under distress. When compared with Sub Sahara African region, on aggregate the cancelled or under distress project makes up about 10 percent of the regional total (PPIAF, 2014).

The deal structure of private participation revealed that the Greenfield projects dominated the transaction dynamic during the period. Greenfield made up 60 percent (figure 4) with a recorded value of over US\$7 billion, though below the sub Saharan regional average of 69.70 percent, was prevalent in the electricity, natural gas, port, ICT and airports. the transaction form most dominant were "Build, operate, and transfer" (BOT) and "Build, own, and operate" (BOO).

The "Build, Own and Operate" constituted 66 percent of the greenfield transaction with the bulk of the investment (64 percent) channeled to the channel dredging and terminal of the Lekki Deep Seaport in the transport sector, while the rest was in Afam VI power electricity generation Project. Also, about 60 percent of the "Build, Operate and Transfer" transactions were also invested in the seaport project while the balance of about 36 percent on the Greater Lagos gas distribution pipeline, West African Gas Pipeline Company Ltd, Okpai Independent Power Project, Agbara/ Ota Natural Gas Pipeline, Murtala Muhammed Terminal 2 projects. 


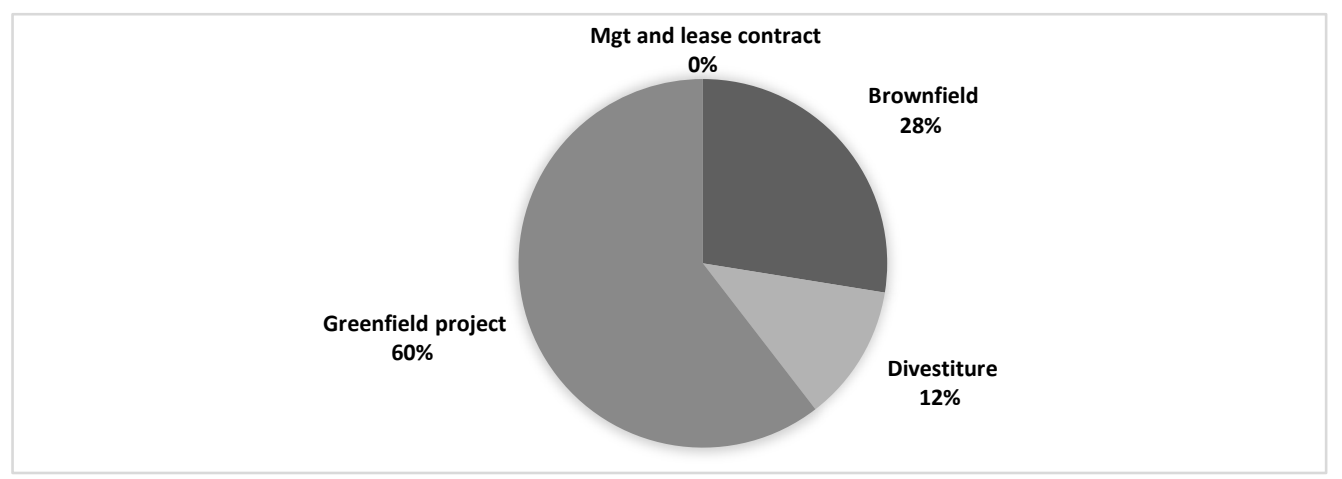

Figure 3. Investment (\%) by type in Nigeria

Figure 3 shows that the brownfield was the second most dominant investment type, representing about 28 percent of the total investment during the review period. The Brownfield investment flow was the dominated transactions in the Port Subsector, with most of the transactions executed through the Rehabilitate, operate, and transfer (ROT) and Rehabilitate, lease or rent, and transfer (RLRT). Over 90 percent of the transaction under brownfield were for the rehabilitation of the various port terminal as well as for the AFAM power project in for the period under review.

divestiture representing 12 percent of total investment over the period under review saw government partial divestment in Egbin power plant, and KEPCO Egbin Power Plant in the energy sector and the government foremost telecommunication company, Nigerian Telecommunications Ltd (NITEL) in the information and communication technology sector which all generated an inflow of over US $\$ 1.4$ billion over the review period (see Table 1) (PPIAF, 2014). The Management and Lease Contract recorded its only transaction during the review period in the Energy sector with just a project with no recorded investment inflows.

Experience with infrastructure development through PPPs like in Nigeria has generally been positive although it is not in all cases that the objective of a PPP arrangement is met given the limited ability of the government to maintain long-term capabilities (Zheng \& Caldwell, 2008). Sometimes it has led to costly disappointments with many more cases of contracts being renegotiated in favor of the concessionaire. Also, empirical verification of the claims to greater efficiency has been very difficult because of the unavailability of long-term financial data or because of political manipulation of accounting procedures (Guasch, 2004; Grimsey \& Lewis, 2005; Shaoul, 2005; Eduardo et al., 2009; and Khadaroo, 2008).

Nigeria's experience has been quite mixed given the period under review. These include successful implementation of the Bus Rapid Transit Scheme, the Lagos Urban Light rail projects, improved waste collection and the partial completion of the $49.4 \mathrm{~km}$ expansion and upgrade of the Lekki Epe express way in Lagos which opened the southern part of Lagos and resulting in massive housing projects never experienced in Nigeria. Also the Akamkpa Toll Road Project and Tinapa Free Trade Zone in Cross Rivers State, the Greater Port Harcourt Housing Scheme in the Rivers State all in the South-South region of the country and the massive water scheme in the south west state of Ekiti and the Teragro Benfruit Plant in Benue State are amongst the success stories of PPP in Nigeria.

However, the Concessioning of one of Nigeria's busiest domestic airport, Muritala Mohammed Domestic Airport, though successful in implementation had issues with the terms, which resulted in litigations. So also, was the concession of one of the nations busy highways, the gate to the commercial capital of Lagos from other part of the country. This concession was eventually cancelled and taken over by the government. Interestingly, the same company handled these two-troubled transactions. Another is the unilateral termination of concession Agreement for the upgrade, installation and management of automated airport service systems between Federal Airports Aviation Authority of Nigeria (FAAN) and Maevis Ltd.

There is no doubt that adequate supply of infrastructure is important. Infrastructure Projects are non-rival in consumption and generate externalities, support economic growth and facilitate changes of economic variables, enhance quality of life and are important for national security and integration into the world economy. The importance of infrastructure is not only for economic benefits, but also for its impact on health, safety, leisure and general aesthetics (Aschauer, 1990; Maffei \& Meredith, 1995; Dasgupta, 1999; Buhr, 2003; UNCTAD, 2008; \& Morimoto, 2010). 


\section{Conclusion}

This paper has expounded further the argument that private participation in the provision of infrastructure is not new in Nigeria. In doing this, it traced the evolution of PPP as an infrastructure provision option, gave a theoretical foundation and discussed the history of how well the private sector had contributed to infrastructure development with focus on the period between 1997 and 2018. The dearth of infrastructure as observed by Age nor (2010) continues to be a key obstacle to growth and development in many low-income countries. The Nigerian experience reflects the theoretical rationalization of X-inefficiency, making the private participation option for the procurement of infrastructure attractive.

With an inefficient bureaucracy, poor maintenance, underinvestment, increasing cost of production and increasing urban expansion, coupled with fiscal challenges, Nigeria like other developing countries adopted, the PPP option and initiated policies to allow the private sector take over the responsibility for building infrastructure, subsequently operating them to provide public goods or services. since long-term economic growth requires investments in infrastructure the PPP initiative enhances the quality of service delivery to support the various industrial sectors. (Hammami et al., 2006; Hoppe et al., 2013).

The question therefore drawing from the study is how well can government keep faith with the private sector, what are the various incentives available and acceptable to attract inflow of private investors and their resource into a country and what are the implications for both parties? To what extent can both parties establish mutually beneficial relationship in order to positively impact national economic growth and corporate business objectives.

\section{References}

Abdullahi, C. B., \& Aziz, A. W. (2010). Nigeria's Housing Policy and Public- Private Partnership (PPP) Strategy: Reflections in Achieving Home Ownership for Low-Income Group in Abuja, Nigeria. 22nd International Housing Conference, ENHR 2010, 4-7 July, ISTANBUL on Urban Dynamics \& Housing Change Crossing into the 2nd Decade of the 3rd Millennium.

Adekunle, A. M. (2011). Public-Private Partnership as a Policy Strategy of Infrastructure Financing in Nigeria.

Afeikhena, J. (2008). Private Sector Participation in Infrastructure in Africa. African Peer Review Mechanism Secretariat (APRM).

Agboli, M. I., \& Emery, J. J. (2005). Encouraging Effective Dialogue and Advocacy in Nigeria: The Better Business Initiative. International Finance Corporation, Private for Enterprise Partnership in Africa (PEP Africa).

Age' nor, P. R. (2010). A Theory of Infrastructure-Led Development. Journal of Economic Dynamics \& Control 34, 932-950. https://doi.org/10.1016/j.jedc.2010.01.009

Ahmed, S. S. (1999). A Road Map for The Establishment of Industrial Partnership Council/Consultative Mechanism in Nigeria. Paper presented at regional workshop on the dynamics \& implication of public private sectors consultative mechanisms in Africa, Dakar, Senegal 18-22.

Alasad, R. (2011). Identifying Demand Risk in Public Private Partnership Infrastructure Projects Presentations at the CIB TG72 /Arcom Doctoral Research Workshop. University of Central Lancashire, UK

Ariyo, A., \& Afeikhena, J. (2004). Utility privatization and the poor: Nigeria in focus. Global Issue Papers, (12).

Aschauer, D. A. (1990) Why is infrastructure important? In Munnell, is there is shortfall in public capital investment (pp. 21-50). Conference series no. 34 Boston, Massachusetts: Federal Reserve Bank of Boston.

Asian Development Bank. (2010). Public-Private Partnership Handbook. Publication Stock No. 071107.

Auriola, E., \& Picard, P. M. (2011). A theory of BOT concession contracts. Journal of Economic Behavior \& Organization, 89, 187-209. https://doi.org/10.1016/j.jebo.2011.10.003

Barker, J., Brooke, G., Ramamurthy, S., \& Wilschetz, T. (2009). A Global Crisis in Infrastructure. KPMG International.

Bloomfield, P. (2006). The challenging business of long-term public-private partnerships: Reflections on local $\begin{array}{lllll}\text { experience. } & \text { Public } & \text { Administration }\end{array}$ https://doi.org/10.1111/j.1540-6210.2006.00597.x

Bortolotti, B. J., D’Souza, M. F., \& Megginson, W. L. (2001). Sources of performance improvements in privatized firms: A clinical study of the global telecommunications industry. University of Oklahoma, Department of Finance Working Paper, FEEM Working Paper, (26.2001). 
https://doi.org/10.2139/ssrn.263219

Broadbent, J., \& Laughlin, R. (2005). The Role of PFI in the UK Government's Modernisation Agenda. Financial Accountability and Management, 21(1), 75-97. https://doi.org/10.1111/j.0267-4424.2005.00210.x

Buhr, W. (2003). What is infrastructure? University of Siegen, Discussion Paper No. 107-03.

Calderón, C., \& Servén, L. (2010a). Infrastructure and Economic Development in Sub-Saharan Africa. Journal of African Economies, (19), AERC Supplement 1, 13-87. https://doi.org/10.1093/jae/ejp022

Calderón, C., \& Servén, L. (2010b). Infrastructure in Latin America. Policy Research Working Paper 5317, World Bank, Washington, DC. https://doi.org/10.1596/1813-9450-5317

Calderón, C., Moral-Benito, E., \& Luis, S. (2011). Is Infrastructure Capital Productive? A Dynamic Heterogeneous Approach. Policy Research Working Paper 5682, World Bank, Washington, DC. https://doi.org/10.1596/1813-9450-5682

Chatterjee, S., \& Mahbub-Morshed, A. K. M. (2011). Infrastructure provision and macroeconomic performance. Journal of Economic Dynamics \& Control, 35, 1288-1306. https://doi.org/10.1016/j.jedc.2011.03.007

Clive, H., Hodges, J., Schur, M., \& Shukla, P. (2003). Infrastructure Projects: A Review of Cancelled Private Projects. Public Policy for the Private Sector Note No. 252, World Bank Washington.

Confederation of British Industry. (2007). Building on Success: The way forward to PFI.

Dasgupta, D. (1999). Growth versus welfare in a model of nonrival infrastructure. Journal of Development Economics, 58, 359-385. https://doi.org/10.1016/S0304-3878(98)00127-8

Dosi, G. (1988). Sources, procedures, and microeconomic effects of innovation. Journal of Economic Literature, 26(3), 1120-171.

Eduardo, E., Fischer, R., \& Galetovic, A. (2009). The Basic Public Finance of Public-Private Partnerships. Working Paper 13284.

Estache, A., Ianchovichina, E., Bacon, R., \& Salamon, I. (2013). Infrastructure and Employment Creation in the Middle East and North Africa. Mimeo, The World Bank. https://doi.org/10.1596/978-0-8213-9665-0

European Commission (EC). (2003). Guidelines for Successful Public Private Partnerships (p. 19). March 2003.

Federal Ministry of Health. (2005). National Policy on Public Private Partnership for Health in Nigeria. Federal Ministry of Health, Federal Republic of Nigeria.

Ghobadian, A., Gallear, D., O’Regan, N., \& Vinery, H. (2004). Public Private Partnerships: Policy and Experience. Basingstoke: Palgrave.

Grimsey, D., \& Lewis, M. K. (2005). Are Public Private Partnerships value for money? Evaluating alternative approaches and comparing academic and practitioner views. Accounting Forum, 29(2005), 345-378. https://doi.org/10.1016/j.accfor.2005.01.001

Groote, P. (1995). Kapitaalvorming in infrastructuur in Nederland 1800-1913. SOM, Groningen.

Guasch, J. L. (2004). Granting and Renegotiating Infrastructure Concessions: Doing it right. Washington: The World Bank. https://doi.org/10.1596/0-8213-5792-1

Hammami, M., Ruhashyankiko, J. F., \& Yehoue, E. B. (2006). Determinants of Public-Private Partnerships in Infrastructure. IMF Working Paper, No WP/06/99. https://doi.org/10.5089/9781451863598.001

Harris, C. (2003). Private Participation in Infrastructure in Developing Countries: Trends, Impacts, and Policy Lessons. World Bank Working Paper No. 5. The International Bank for Reconstruction and Development / The World Bank.

Hassan, A., Idu, A. Y., Uyo, A. J., \& Ogbole, O. J. (2012). Rethinking Poverty Reduction and Sustainable Development in Nigeria: An Advocacy for the Bottom-Top Paradigm. Canadian Social Science, 8(6), 78-90.

Hill, H. (2004). Six Asian Economies: Issues and Lessons. In D. H. Brooks, \& H. Hill (Eds.), Managing FDI in a Globalizing Economy: Asian Experiences (pp. 29-78). London: Palgrave Macmillan.

HM Treasury. (1997). The Green book: Economic Appraisal in Central Government - A Technical Guide for Government Departments, HMSO, London.

Hodge, G., \& Greve, C. (2007). Public-Private Partnerships: An International Review. Public Administration 
Review, 67(3), 545-558. https://doi.org/10.1111/j.1540-6210.2007.00736.x

Hodge, G., \& Greve, C. (2011). Theorizing Public-Private Partnership Success: A Market-Based Alternative to Government? Paper for the Public Management Research Conference at Syracuse University 2-4 June 2011, Syracuse, NY, USA Themed Panel on 'Market-Based Alternatives to Government'.

Holmstrom, B., \& Milgrom, P. (1991). Multitask Principal-Agent Analyses: Incentive Contracts, Asset Ownership and Job Design. Journal of Law, Economics and Organization, 7, 24-52. https://doi.org/10.1093/jleo/7.special_issue.24

Hoppe, E. I., David, J. K., \& Patrick, W. S. (2013). Public-private partnerships versus traditional procurement: An experimental investigation. Journal of Economic Behavior \& Organization, 89, 145-166. https://doi.org/10.1016/j.jebo.2011.05.001

Hudon, P. A. (2011). A Critique of Public-Private Partnerships in Quebec Democratic Deficiencies and Unethical Procurement. Public Integrity, 13(3), 257-273. https://doi.org/10.2753/PIN1099-9922130306

Jensen, M., \& Meckling, W. (1976). Theory of the firm: Managerial behavior, agency costs and ownership structure. Journal of Financial Economics, 3(4), 305-60. https://doi.org/10.1016/0304-405X(76)90026-X

Khadaroo, I. (2005). An Institutional Theory Perspective on the UK's Private Finance Initiative (PFI) Accounting Standard Setting Process. Public Management Review, 7(1), 69-94. https://doi.org/10.1080/1471903042000339428

Khadaroo, I. (2008). The Actual Evaluation of School PFI Bids for Value for Money in the UK Public Sector. Critical Perspectives on Accounting, 19(8), 1321-1345. https://doi.org/10.1016/j.cpa.2007.05.001

Kim, B. (2006). Infrastructure Development for the Economic Development in Developing Countries: Lessons from Korea and Japan. GSICS Working Paper Series No. 11.

Kwak, Y., Chih, Y., \& Ibbs, C. W. (2009). Towards a comprehensive understanding of public private partnerships for infrastructure development. California Management Review, 51(2), 51-78. https://doi.org/10.2307/41166480

Lagos Chamber of Commerce and Industry. (2013). Profile of The Lagos Chamber Of Commerce and Industry.

Leibenstein, H. (1966). Allocative Efficiency vs. 'X-Efficiency'. American Economic Review, 56(3), 392-415.

Mabogunje, A. L. (2007). Thirty Years After: Reflections on the Development Process in Nigeria. Faculty Distinguished Lecture Series No 2, University of Ibadan: Faculty of Social Sciences, 24 November.

Maffei, J. O., \& Meredith, J. (1995). Infrastructure and flexible manufacturing technology: Theory development. Journal of Operations Management, 13, 273-298. https://doi.org/10.1016/0272-6963(95)00034-8

Markab Advisory. (2012). Public private partnership: A vehicle of excellence for the next wave of infrastructure development IN the GCC. Qatar Financial Center Authority / Markab Advisory.

Martimort, D., \& Pouyet, J. (2006). "Build It or Not": Normative and Positive Theories of Public-Private Partnerships. Journal of Economic Literature.

Mayaki, I. (2014). Why Infrastructure Development in Africa Matters.

Mitchell-Weaver, C., \& Manning, B. (1991). Public private partnerships in third world development: A conceptual overview. Studies in Comparative International Development, 26(4), 45-67. https://doi.org/10.1007/BF02743762

Morimoto, R. (2010). Estimating the benefits of effectively and proactively maintaining infrastructure with the innovative Smart Infrastructure sensor system. Social-Economic Planning Sciences, 44, 247-257. https://doi.org/10.1016/j.seps.2010.07.005

Nedozi, F. O., Obasanmi, J. O., \& Ighata, J. A. (2014). Infrastructural development and economic growth in Nigeria: Using Simultaneous equation. Journal of Economics, 5(3), 325-332. https://doi.org/10.1080/09765239.2014.11885008

Ohia, U. (2011). Infrastructure Concession In Nigeria: Challenges And Opportunities. A Paper Presented At The 5th National Diaspora Conference 2011 Diaspora Day Held at the Congress Hall, Transcorp Hilton Hotel, Abuja 25-27 July, 2011.

Osborne, S. P. (2000). Public-Private Partnerships: Theory and Practice in International Perspective. London: Routledge. 
Public-Private Infrastructure Advisory Facility (PPIAF). (2014). PPIAF Assistance in the Federal Republic of Nigeria.

Raisbeck, P., Duffield, C., \& Xu, M. (2010). Comparative performance of PPPs and traditional procurement in $\begin{array}{llll}\text { Australia. } \quad \text { Construction } & \text { Management and }\end{array}$ https://doi.org/10.1080/01446190903582731

Reside, R. E., \& Mendoza, A. M. (2010). Determinants of Outcomes of Public-Private Partnerships (PPP) in Infrastructure in Asia. Discussion Paper No. 2010-03 University of the Philippines School of Economics.

Ros, A. (1999). Does Ownership or Competition Matter? The Effects of Tele-communication Reform on Network Expansion and Efficiency. Journal of Regulatory Economics, 15, 65-92. https://doi.org/10.1023/A:1008048924876

Sachs, J. D., Mcarthur, J. W., Schmidt-Traub, G., Kruk, M., Bahadur, C., Michael, F., \& Mccord, G. (2004). Ending Africa's Poverty Trap. Brookings Papers on Economic Activity, 117-240. https://doi.org/10.1353/eca.2004.0018

Sagagi, M. S. (2007). Public-Private Dialogue: Myth Or Reality. A Paper Presented at the Joint Annual General Meeting of the Manufacturers Association of Nigeria held at Royal Tropicana hotel on $13^{\text {th }}$ December 2007.

Sala-i-Martin, X., \& Subramanian, A. (2003). Addressing the Natural Resource Curse: An Illustration from Nigeria. NBER Working Paper Series, Working Paper 9804. https://doi.org/10.3386/w9804

Schwartz, J., Luis, A. A., \& Georgeta, D. (2009). Crisis in Latin America Infrastructure Investment, Employment and the Expectations of Stimulus. World Bank Policy Research Working Paper No.5009. https://doi.org/10.1596/1813-9450-5009

Shaoul, J. (2005). A Critical Financial Analysis of the Private Finance Initiative: Selecting a Financing Method or Allocating Economic Wealth? Critical Perspectives on Accounting, 16(4), 441-471. https://doi.org/10.1016/j.cpa.2003.06.001

Sotola, O., \& Ayodele, T. (2011). Public-Private Partnership: Will it Fix Infrastructure in Nigeria. Initiative for Public Policy Analysis Policy Paper.

Straub, S. (2008). Infrastructure and Growth in Developing Countries: Recent Advances and Research Challenges. World Bank Policy Research Working Paper No 4460. https://doi.org/10.1596/1813-9450-4460

Sunita, K., \& Nellis, J. (2002). Privatization in Competitive Sectors: The Record to Date. Policy Research Working Paper, World Bank, Washington.

Tiča, B., \& Zajc, K. (2010). Public-Private Partnerships in Slovenia: Recent Developments and Perspectives. Review of Central and East European Law, 35, 191-215. https://doi.org/10.1163/157303510X12650378240232

Udah, E. B., \& Obguagu, R. (2011). Constraints to Economic Development and Growth in Nigeria. European Journal of Scientific Research, 65(4), 581-593.

United Nations Conference on Trade and Development (UNCTAD). (2008). Transnational Corporations and the Infrastructure Challenge. World Investment Report 2008: United Nations Conference on Trade and Development.

Vining, A., \& Boardman, A. (2008). Public--Private Partnerships: Eight Rules for Governments. Public Works Management \& Policy, 13(2), 149. https://doi.org/10.1177/1087724X08323843

Weihe, G. (2005). Public-Private Partnerships, addressing a Nebulous Concept. Working Paper No. 16, Copenhagen, International Center for Business and Politics, Copenhagen Business School.

Wiegmans, B. W., Kievits, M., \& Spit, T. (2005). Concessions to PPP? A perspective on infrastructure development in the EU. Proceeding at the $45^{\text {th }}$ Congress of the European Regional Science Association. Land Use and Water Management in a Sustainable Network Society.

World Bank. (2004). Guidelines: Procurement under IBRD Loans and IDA Credits.

Yescombe, E. R. (2007). Public-Private Partnerships: Principles of Policy and Finance. Butterworth-Heinemann, Elsevier. https://doi.org/10.1016/B978-075068054-7.50025-3

Zheng, J., \& Caldwell, N. (2008). An Asymmetric Learning in Complex Public-Private Projects. Journal of Public Procurement, 8(3), 334-355. https://doi.org/10.1108/JOPP-08-03-2008-B004 


\section{Copyrights}

Copyright for this article is retained by the author(s), with first publication rights granted to the journal.

This is an open-access article distributed under the terms and conditions of the Creative Commons Attribution license (http://creativecommons.org/licenses/by/4.0/). 